【原著】

\title{
ガゴメ昆布フコイダンの健常成人における安全性 \\ Safety of fucoidan from Gagome kombu (Kjellmaniella crassifolia) in healthy adult volunteers
}

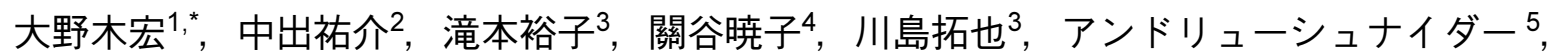 \\ 新井隆成 ${ }^{5}$, 上馬塲和夫 ${ }^{6}$, 鈴木信孝 $^{3}$ \\ Hiromu OHNOGI ${ }^{1, *}$, Yusuke NAKADE ${ }^{2}$, Yuko TAKIMOTO ${ }^{3}$, Akiko SEKIYA $^{4}$, \\ Takuya KAWASHIMA ${ }^{3}$, Andrew SCHNEIDER $^{5}$, Takanari ARAI ${ }^{5}$, \\ Kazuo UEBABA ${ }^{6}$, Nobutaka SUZUKI ${ }^{3}$ \\ 1 タカラバイオ株式会社 \\ 2 金沢大学医学部附属病院 \\ 3 金沢大学大学院医学系研究科臨床研究開発補完代替医療学講座 \\ ${ }^{4}$ 金沢大学大学院医学系研究科 保健学専攻 病態検査学講座 \\ ${ }^{5}$ 金沢大学大学院医学系研究科 周生期医療専門医養成学講座 \\ 6 帝京平成大学東洋医学研究所
}

【要 旨】

ガゴメ昆布 (Kjellmaniella crassifolia) 由来の フコイダンを配合した飲料のヒトへの安全性 について評価を行った. インフォームドコン セントの得られた健常成人ボランティア 32 名を 8 名ずつ 4 群に無作為に割り付け， 2 種 類のガゴメ昆布フコイダン配合飲料のそれぞ れの 1 日目安量ならびに過剩量（3 倍量）を 4 週間摂取させた. 摂取前後に血液検査, 尿 検査, QOL 調査, 免疫機能検査などを行っ た. その結果, 試験期間中, いずれの摂取群 においても安全上問題となる検査値の変動例 はなかった. また，ガゴメ昆布フコイダン配 合飲料に関連し安全性に問題となる有害な事 象は見られなかった. 加えて，免疫機能検査 においては Th1 の増加が認められた. 以上, 健常成人を対象としたヒト摂取試験によりガ ゴメ昆布フコイダンを配合した飲料の安全性 が示された.

【キーワード】

フコイダン, ガゴメ昆布, 安全性, 免疫機能
はじめに

近年の急速な高齢化社会への移行や医療制度問題を背 景に, 疾病を未然に防ぐ予防医学の重要性や, 疾病の治 療や患者の QOL（生活の質）向上に打ける代替医療の必 要性が高まっている. 中でも食品の果たす役割は大きく, 最近では食品の三次機能としての生体調節機能に関する 研究が盛んに進められ, 生活習慣病や関節炎, 骨粗鬆症, アレルギー，がんなど様々な疾病の予防・治療への応用 が期待されている.

フコイダンは, 昆布やワカメ, モズクなど褐藻類に含 まれるぬめり成分であり, 硫酸化されたフコースを主要 な構成糖とする多糖の総称である. 近年, フコイダンの 機能性について研究が進められ, 免疫賦活作用や抗腫瘍 作用, 血液凝固抑制作用, 抗ウイルス作用など多様な機 能性が研究されている1). さらに，海藻の種類によって フコイダンの糖組成や硫酸基含量が異なることがわかっ て扣り，それらが生理活性の強さにも影響することが報 告されている2-4).

北海道の函館近海に生育するガゴメ昆布 (Kjellmaniella

受理日：2011 年 5 月 26 日

* †520-2193 滋賀県大津市瀬田三丁目 4 番 1 号タカラバイオ株式会社 Tel: 077-543-7201 Fax: 077-543-7238 E-mail: onogih@takara-bio.co.jp 
crassifolia) は真昆布などの他の昆布に比べてフコイダン を多く含有し，F-フコイダン，U-フコイダン, G-フコイ ダンの 3 種の主要なフコイダンを含んでいることが明ら かになっている2)。 また，動物や培養細胞を用いた試験 により，ガゴメ昆布フコイダンには抗腫瘍作用，免疫賦 活作用，血栓形成抑制作用，インフルエンザ予防作用， 育毛作用など多様な生理活性が認められている3,5,6). ガ ゴメ昆布フコイダンはマクロファージなどからの IL-12 の産生や, リンパ球からの IFN- $\gamma$ の産生を強く促進する. また，ガゴメ昆布フコイダンは NK 細胞を活性化するこ とにより抗腫瘍作用を発揮する。 さらに, ガゴメ昆布フ コイダンは腸管のパイエル板からの IFN- $\gamma$ 産生を促進す ることも知られている77.

ガゴメ昆布フコイダンは原料であるガゴメ昆布の長い 食経験から安全性が極めて高い食品素材と考光られる。 また，細菌を用いた復帰突然変異試験や培養細胞を用い た染色体異常試験，マウスを用いた小核試験などの各種 遺伝毒性試験によっても安全性が確認されている ${ }^{8}$. ᄂ かしながら，ガゴメ昆布フコイダンのヒトへの安全性を 詳しく評価した報告はない。加えて，ガゴメ昆布フコイ ダンはそれ単独だけではなく,ブナシメジやアガリクス, 霊芝などのきのこ由来素材と組み合わせて利用されるこ ともあり, その場合の七トに対する安全性の情報も必要 である. 本研究ではガゴメ昆布フコイダンのヒトへの安 全性を評価し，加えてヒトの免疫機能への影響を探索的 に評価することを目的に，健常成人を対象とした安全性 試験を実施した。

\section{材料と方法}

\section{1. 試験食品}

ガゴメ昆布フコイダンは, 乾燥ガゴメ昆布破砕物を原 料に, 塩化カルシウム存在下で熱水抽出を行い, 限外濾 過によりヨウ素や塩分などの低分子成分を除いた後, 濃 縮・殺菌したものを使用した。本研究では，このガゴメ 昆布フコイダンを 1 日目安量として 200 あるいは $300 \mathrm{mg}$ 配合した 2 種類の飲料（タカラバイオ（株）製造）を試 験食品として用いた．表 1 と試験食品の配合成分名と栄 養成分を示した．飲料 1 はガゴメ昆布フコイダンを $200 \mathrm{mg}$ 配合した液量 $50 \mathrm{ml}$ の飲料であり, ガラス瓶容器 に入れ殺菌処理後室温保存した. 飲料 2 はガゴメ昆布フ コイダンを $300 \mathrm{mg}$ と白榆木茸属キノコエキスを 7,500 mg 配合した液重量 $45 \mathrm{~g}$ の飲料であり, レトルト袋 に入れ殺菌処理後室温保存した. な报, 飲料 2 の白检木 茸属キノコエキスとはブナシメジ（K-3128 株）を原料に アルカリ性熱水抽出により得られたエキスであり, 特徵 的な成分としてきのこテルペン (Hypsiziprenol $\mathrm{A}_{9}$ )を含 屯.

\section{2. 被験者}

以下の被験者選択基準扣よび除外基準を満たした健常 成人 32 名を本試験の被験者とした。

選択基準

1) 医師の診察によって証明された健常成人

2) 本試験開始前 2 週間以内に健康食品を摂取していない 者

3) 20 歳以上 70 歳未満の者

表 1 試験食品

\begin{tabular}{|c|c|c|c|c|}
\hline 試験食品 & $\begin{array}{c}\text { 内容量 } \\
(1 \text { 食あたり })\end{array}$ & 配合成分名 & 栄養成分（1 食あた & \\
\hline 飲料 1 & $50 \mathrm{ml} /$ 本 & $\begin{array}{l}\text { フコイダン含有昆布抽出 } \\
\text { 物, 麦芽糖, モン果 } \\
\text { 汁, 梅肉粉末, 安定剂 } \\
\text { (ペクチン), 香料, 酸味 } \\
\text { 料, ビタミン C }\end{array}$ & $\begin{array}{l}\text { エネルギー } \\
\text { 蛋白質 } \\
\text { 脂質 } \\
\text { 炭水化物 } \\
\text { ナトリウム } \\
\text { ヨウ素 } \\
\text { フコイダン }\end{array}$ & $\begin{array}{r}8 \mathrm{kcal} \\
0 \mathrm{~g} \\
0 \mathrm{~g} \\
2.1 \mathrm{~g} \\
9 \mathrm{mg} \\
0 \mathrm{mg} \\
200 \mathrm{mg}\end{array}$ \\
\hline 飲料 2 & $45 \mathrm{~g}$ /袋 & $\begin{array}{l}\text { フコイダン含有昆布抽出 } \\
\text { 物, 白榆木茸属キノコエ } \\
\text { キス, トレハロース, ス } \\
\text { イートコーンパウダー, } \\
\text { 紅茶エキス, 甘味料 } \\
\text { (ソーマチン, スクラ } \\
\text { ロース), 香料, 酸味料, } \\
\text { 乳化剂 (大豆由来) }\end{array}$ & $\begin{array}{l}\text { エネルギー } \\
\text { 蛋白質 } \\
\text { 脂質 } \\
\text { 炭水化物 } \\
\text { ナトリウム } \\
\text { ヨウ素 } \\
\text { フコイダン } \\
\text { 白榆木茸属キノコエキス }\end{array}$ & $\begin{array}{r}15 \mathrm{kcal} \\
0.6 \mathrm{~g} \\
0.3 \mathrm{~g} \\
2.5 \mathrm{~g} \\
42 \mathrm{mg} \\
0 \mathrm{mg} \\
300 \mathrm{mg} \\
7500 \mathrm{mg}\end{array}$ \\
\hline
\end{tabular}


4) 試験参加について被験者本人から文書で同意が得ら れている者

5) 以下のすべてを満たし, 主要臓器機能が保持されてい る者

・血色素量 : $\geqq 10.0 \mathrm{~g} / \mathrm{dl}$

・血清 AST 括よびALT : 基準値の 2.5 倍未満

- 白血球数 : $\geqq 4,000 / \mathrm{mm}^{3}$, かつ $\leqq 12,000 / \mathrm{mm}^{3}$

・血清総ビリルビン值 : $<1.5 \mathrm{mg} / \mathrm{dl}$

- 血小板数 : $\geqq 100,000 / \mathrm{mm}^{3}$

・血清クレアチニン值 : $<2.0 \mathrm{mg} / \mathrm{dl}$

除外基準

1) 登録時，健康食品を摂取している者. ただし 2 週間の 無摂取期間を設けた場合はこの限りではない。

2) フコイダン, 海藻, キノコ, その他配合成分にアレル ギーのある者

3) 妊娠している者, 試験期間中妊娠の意志のある者, 授 乳中の者

4) その他, 医師が対象として不適当と判断した者

試験前に被験者には書面にてインフォームドコンセント を実施し, 試験の目的や方法, 参加と撤回の自由などに ついて十分に説明し，文書にて参加の同意を得た.

\section{3. 試験方法}

試験は無作為化 4 群割り付けオープン試験で実施し た. 試験への参加に関して同意が得られた被験者 32 名を 無作為に以下の 4 群に割り付け, 試験食品の規定量を 4 週間摂取してもらい, その間の有害事象の有無, 摂取前 後での血液・尿検查，QOL 調查などを行った。また，摂 取終了後 2 週間を後観察期間とした.

1) 飲料 11 日目安量摂取群 (以下, 1 本摂取群)

2) 飲料 11 日目安の 3 倍量摂取群 (以下, 3 本摂取群)

3) 飲料 21 日目安量摂取群（以下， 1 袋摂取群）

4) 飲料 21 日目安の 3 倍量摂取群 (以下, 3 袋摂取群)

\section{4. 検査項目}

摂取開始前に被験者背景を，摂取 4 週間後に摄取状況 の調查を行った. 摂取開始前と摂取 4 週間後に一般所見, 血液検查, 尿検查, 血液凝固系検查, QOL 調查, 自他覚
症状と有害事象の調查, 免疫機能検査を行った。 また, 後観察期間に颃いて自他覚症状と有害事象の調査を引き 続き行った. 一般所見は体温, 血圧, 心拍数を測定した. 血液検查は血液生化学検査（総蛋白，アルブミン，AST, ALT, ALP, $\gamma$-GTP, コリンエステラーゼ，総ビリルビ ン，総コレステロール，HDL-コレステロール，LDL-コ レステロール, 中性脂肪, 尿素窒素, クレアチニン, $\mathrm{Na}$, $\mathrm{Cl}, \mathrm{K}$ ) ならびに血液学的検査 (白血球数, 赤血球数, 血 色素量, ヘマトクリット, $\mathrm{MCV}, \mathrm{MCH}, \mathrm{MCHC}$, 血小板 数, 白血球分画）を実施した。尿検查は, 蛋白, 糖, 潜 血, ウロビリノーゲンを測定した。血液凝固系検査はプ ロトロンビン時間 (PT), 活性化部分トロンボプラスチン 時間 (APTT) などを測定した. QOL 調査は SF-36V2 ${ }^{\mathrm{TM}}$ 版 を用いて行った，有害事象はCommon Terminology Criteria for Adverse Events v3.0 (CTCAE v3.0) 飞従い調査 した. 免疫機能検査は飲料 1 の 1 本摂取群ならびに飲料 2 の 1 袋摂取群に颃いて実施し, 血中の NK 活性, Th1/ Th2を測定した.

\section{5. 統計解析}

群内での摂取前後比較は, paired $t$-test で行った. QOL 調查の結果は, 標準化得点に直して paired $t$-test で検定し た．有意水準は両側検定で $5 \%$ 未満とした．統計解析》 フトはSPSS $11.5 \mathrm{v} を$ 使った。

\section{6. 倫理的事項}

本試験は, ヒトを対象とした研究に関するへルシンキ 宣言を遵守しながらプロトコールを作成し, 日本補完代 替医療学会倫理委員会の承認を得た後に実施された。

\section{結 果}

\section{1. 被験者背景・摂取コンプライアンス}

被験者背景と摂取コンプライアンスを表 2 に示した. 各群 8 名, 男女 4 名ずつがエントリーしたが年齢に群間 差は認められなかった。摂取コンプライアンスは全被験 者平均では $83.6 \%$ と十分であったが, 飲料 2 の 3 本椇取 群では平均 $76.6 \%$ と比較的低值であった。

表 2 被験者背景・黍取コンプライアンス

\begin{tabular}{|c|c|c|c|c|}
\hline & $\begin{array}{c}\text { 飲料 } 1 \\
1 \text { 本摂取群 }\end{array}$ & $\begin{array}{c}\text { 飲料 } 1 \\
3 \text { 本摂取群 }\end{array}$ & $\begin{array}{c}\text { 飲料 } 2 \\
1 \text { 袋摂取群 }\end{array}$ & $\begin{array}{c}\text { 飲料 } 2 \\
3 \text { 袋摂取群 }\end{array}$ \\
\hline 人数 & 8 & 8 & 8 & 8 \\
\hline 男性／女性（人） & $4 / 4$ & $4 / 4$ & $4 / 4$ & $4 / 4$ \\
\hline 年齢 & $25.0 \pm 3.7$ & $23.6 \pm 4.0$ & $26.5 \pm 9.7$ & $23.9 \pm 3.9$ \\
\hline 摂取コンプライアンス & $89.1 \pm 15.0$ & $82.5 \pm 12.9$ & $86.1 \pm 13.2$ & $76.6 \pm 9.7$ \\
\hline
\end{tabular}

数值は平均值土標準偏差 


\section{2. 血液検査}

血液生化学的検査の結果を表 3 に示した．飲料 1 の 1 本拱取群に打いて総蛋白の有意な上昇, 飲料 2 の 1 袋摂 取群に扣いて $\gamma$-GTP の有意な上昇, 飲料 2 の 3 袋摂取群 に损いて HDL-コレステロールの有意な低下がそれぞれ 認められたが，いずれも基準值範囲内での変動であり， 安全上問題となるものではなかった。血液学的検查の結 果を表 4 亿示した。飲料 1 の 3 本摄取群において MCV の有意な低下が認められたが，基準值範囲内の変動であ り安全上問題となるものではなかった。

\section{3. 尿検査 $\cdot$ 血圧 $\cdot$ 心拍数}

尿検查・血圧・心拍数の結果を表 5 亿示した。尿蛋白 に打いては, 32 名の被験者中, 陽性から陰性反応への改 善が 3 例, 偽陽性反応から陰性反応への変化が 1 例, 陰 性反応から偽陽性反応への変化が 2 例認められた。尿糖 では異常は認められなかった，尿潜血に打いては，偽陽 性反応から陰性反応への改善が 1 例, 陰性反応から偽陽 性反応への変化が 1 例認められた。 ウロビリノーゲンに 扔いては陽性から陰性反応への改善が 1 例認められた。 また血圧，心拍数にも異常は認められなかった.

表 3 血液生化学的検查

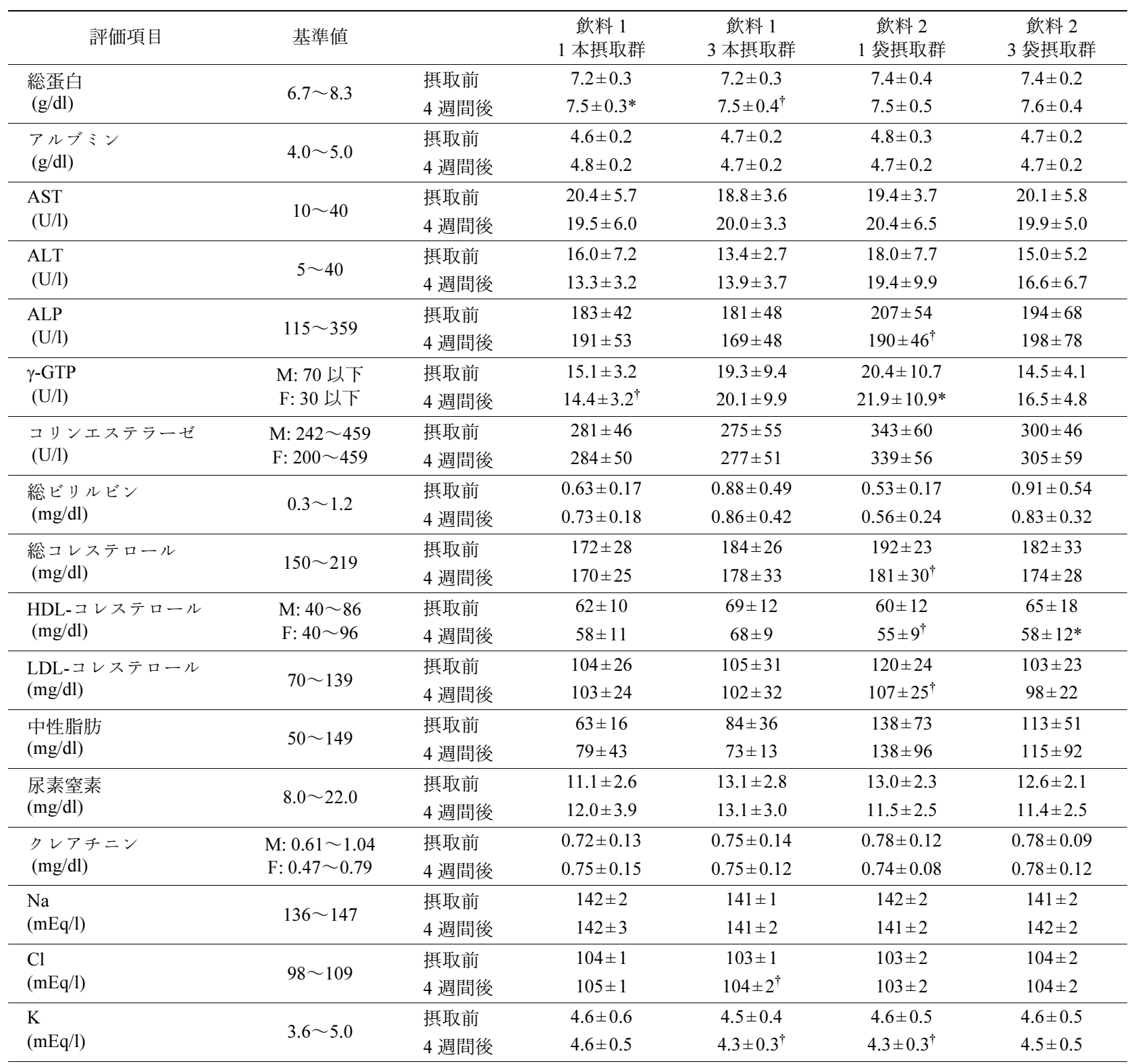

数值は平均值土標準偏差

摂取前との比較 : ${ }^{\dagger} \mathrm{p}<0.1,{ }^{*} \mathrm{p}<0.05$ 
表 4 血液学的検査

\begin{tabular}{|c|c|c|c|c|c|c|}
\hline 評価項目 & 基準值 & & $\begin{array}{c}\text { 飲料 } 1 \\
1 \text { 本摂取群 }\end{array}$ & $\begin{array}{c}\text { 飲料 } 1 \\
3 \text { 本摂取群 }\end{array}$ & $\begin{array}{c}\text { 飲料 } 2 \\
1 \text { 袋掑取群 }\end{array}$ & $\begin{array}{c}\text { 飲料 } 2 \\
3 \text { 袋掑取群 }\end{array}$ \\
\hline \multirow{2}{*}{$\begin{array}{l}\text { 白血球数 } \\
(/ \mu \mathrm{l})\end{array}$} & M: $3900 \sim 9800$ & 摂取前 & $5300 \pm 1385$ & $5325 \pm 1063$ & $5650 \pm 2332$ & $5325 \pm 1559$ \\
\hline & $\mathrm{F}: 3500 \sim 9100$ & 4 週間後 & $5438 \pm 1235$ & $5075 \pm 833$ & $5413 \pm 2185$ & $4925 \pm 1026$ \\
\hline \multirow{2}{*}{$\begin{array}{l}\text { 赤血球数 } \\
\left(\times 10^{4} / \mu \mathrm{l}\right)\end{array}$} & M: 427〜 570 & 摂取前 & $467 \pm 25$ & $462 \pm 32$ & $485 \pm 71$ & $473 \pm 31$ \\
\hline & $\mathrm{F}: 376 \sim 500$ & 4 週間後 & $476 \pm 23$ & $472 \pm 37$ & $471 \pm 64^{\dagger}$ & $469 \pm 39$ \\
\hline \multirow{2}{*}{$\begin{array}{l}\text { 血色素量 } \\
(\mathrm{g} / \mathrm{dl})\end{array}$} & M: $13.5 \sim 17.6$ & 摂取前 & $13.7 \pm 0.9$ & $13.6 \pm 1.1$ & $14.2 \pm 2.0$ & $14.0 \pm 1.6$ \\
\hline & $\mathrm{F}: 11.3 \sim 15.2$ & 4 週間後 & $14.0 \pm 0.7^{\dagger}$ & $13.6 \pm 1.2$ & $13.9 \pm 1.7$ & $13.9 \pm 1.7$ \\
\hline \multirow{2}{*}{$\begin{array}{l}\text { 血色素量 } \\
(\%)\end{array}$} & M: $84 \sim 110$ & 摂取前 & $85.6 \pm 5.9$ & $84.8 \pm 6.7$ & $89.0 \pm 12.1$ & $87.8 \pm 9.9$ \\
\hline & $\mathrm{F}: 70 \sim 95$ & 4 週間後 & $87.6 \pm 4.1^{\dagger}$ & $84.8 \pm 7.6$ & $86.9 \pm 10.5$ & $86.4 \pm 10.6$ \\
\hline \multirow{2}{*}{$\begin{array}{l}\text { ヘマトクリット } \\
(\%)\end{array}$} & M: $39.8 \sim 51.8$ & 摂取前 & $42.2 \pm 2.5$ & $41.6 \pm 2.2$ & $43.1 \pm 5.0$ & $42.5 \pm 4.2$ \\
\hline & F: $33.4 \sim 44.9$ & 4 週間後 & $42.7 \pm 1.9$ & $41.3 \pm 2.7$ & $41.9 \pm 4.2^{\dagger}$ & $41.9 \pm 4.6$ \\
\hline \multirow{2}{*}{$\begin{array}{l}\text { MCV } \\
\text { (fl) }\end{array}$} & M: $82.7 \sim 101.6$ & 摂取前 & $90.5 \pm 3.4$ & $88.4 \pm 4.6$ & $89.2 \pm 4.6$ & $89.7 \pm 3.4$ \\
\hline & F: $79.0 \sim 100.0$ & 4 週間後 & $89.7 \pm 3.0$ & $87.7 \pm 4.0^{*}$ & $89.3 \pm 4.4$ & $89.2 \pm 3.4$ \\
\hline \multirow{2}{*}{$\begin{array}{c}\mathrm{MCH} \\
(\mathrm{pg})\end{array}$} & M: $28.0 \sim 34.6$ & 摂取前 & $29.3 \pm 1.1$ & $28.8 \pm 1.9$ & $29.5 \pm 1.7$ & $29.6 \pm 1.8$ \\
\hline & $\mathrm{F}: 26.3 \sim 34.3$ & 4 週間後 & $29.5 \pm 1.1$ & $28.8 \pm 2.1$ & $29.6 \pm 1.4$ & $29.5 \pm 1.9$ \\
\hline \multirow{2}{*}{$\begin{array}{l}\text { MCHC } \\
(\%)\end{array}$} & M: $31.6 \sim 36.6$ & 摂取前 & $32.4 \pm 0.6$ & $32.5 \pm 1.2$ & $33.0 \pm 0.9$ & $33.0 \pm 1.0$ \\
\hline & $\mathrm{F}: 30.7 \sim 36.6$ & 4 週間後 & $32.9 \pm 0.5^{\dagger}$ & $32.8 \pm 1.2$ & $33.1 \pm 0.9$ & $33.0 \pm 1.1$ \\
\hline \multirow{2}{*}{$\begin{array}{l}\text { 血小板数 } \\
\left(\times 10^{4} / \mu \mathrm{l}\right)\end{array}$} & M: $13.1 \sim 36.2$ & 摂取前 & $22.3 \pm 5.7$ & $25.7 \pm 3.4$ & $25.4 \pm 2.3$ & $24.0 \pm 5.5$ \\
\hline & F: $13.0 \sim 36.9$ & 4 週間後 & $22.6 \pm 7.6$ & $24.7 \pm 3.8$ & $24.9 \pm 2.8$ & $25.2 \pm 6.6$ \\
\hline \multirow{2}{*}{$\begin{array}{l}\text { 好中球 } \\
(\%)\end{array}$} & \multirow{2}{*}{$40.0 \sim 74.0$} & 摂取前 & $55.4 \pm 8.2$ & $58.4 \pm 6.5$ & $57.3 \pm 10.0$ & $59.0 \pm 5.6$ \\
\hline & & 4 週間後 & $54.6 \pm 9.2$ & $55.4 \pm 8.3$ & $52.7 \pm 8.0$ & $53.5 \pm 11.3$ \\
\hline \multirow{2}{*}{$\begin{array}{c}\text { 好酸球 } \\
(\%)\end{array}$} & \multirow{2}{*}{$0.0 \sim 6.0$} & 摂取前 & $3.7 \pm 2.4$ & $1.7 \pm 0.8$ & $2.6 \pm 1.6$ & $2.3 \pm 0.7$ \\
\hline & & 4 週間後 & $3.6 \pm 2.4$ & $2.3 \pm 2.0$ & $4.2 \pm 4.4$ & $3.5 \pm 2.3$ \\
\hline \multirow{2}{*}{$\begin{array}{l}\text { 好塩基球 } \\
(\%)\end{array}$} & \multirow{2}{*}{$0.0 \sim 2.0$} & 摂取前 & $0.5 \pm 0.2$ & $0.5 \pm 0.2$ & $1.0 \pm 1.4$ & $0.5 \pm 0.3$ \\
\hline & & 4 週間後 & $0.6 \pm 0.2$ & $0.4 \pm 0.3$ & $0.8 \pm 0.4$ & $0.6 \pm 0.5$ \\
\hline \multirow{2}{*}{$\begin{array}{l}\text { リンパ球 } \\
(\%)\end{array}$} & \multirow{2}{*}{$18.0 \sim 59.0$} & 摂取前 & $36.1 \pm 7.1$ & $35.2 \pm 5.8$ & $33.9 \pm 8.8$ & $33.2 \pm 5.6$ \\
\hline & & 4 週間後 & $36.7 \pm 7.7$ & $36.7 \pm 7.4$ & $36.9 \pm 5.5$ & $36.9 \pm 9.5$ \\
\hline \multirow{2}{*}{$\begin{array}{l}\text { 単球 } \\
(\%)\end{array}$} & \multirow{2}{*}{$0.0 \sim 8.0$} & 摂取前 & $4.4 \pm 0.7$ & $4.2 \pm 0.9$ & $5.6 \pm 1.9$ & $5.0 \pm 1.6$ \\
\hline & & 4 週間後 & $4.6 \pm 1.3$ & $5.3 \pm 1.2^{\dagger}$ & $5.4 \pm 2.1$ & $5.5 \pm 1.5$ \\
\hline \multirow{2}{*}{ 顆粒／リンパ球 } & & 摂取前 & $0.63 \pm 0.20$ & $0.60 \pm 0.17$ & $0.59 \pm 0.24$ & $0.55 \pm 0.15$ \\
\hline & & 4 週間後 & $0.65 \pm 0.20$ & $0.65 \pm 0.21$ & $0.65 \pm 0.15$ & $0.68 \pm 0.31$ \\
\hline
\end{tabular}

数值は平均值土標準偏差

摂取前との比較 : ${ }^{\dagger} p<0.1,{ }^{*} p<0.05$

表 5 尿検査 - 血压 $\cdot$ 心拍数

\begin{tabular}{|c|c|c|c|c|c|}
\hline 評価項目 & & $\begin{array}{c}\text { 飲料 } 1 \\
1 \text { 本摂取群 }\end{array}$ & $\begin{array}{c}\text { 飲料 } 1 \\
3 \text { 本摂取群 }\end{array}$ & $\begin{array}{c}\text { 飲料 } 2 \\
1 \text { 袋摂取群 }\end{array}$ & $\begin{array}{c}\text { 飲料 } 2 \\
3 \text { 袋摂取群 }\end{array}$ \\
\hline 尿蛋白 & & 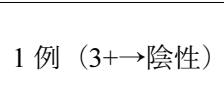 & 1 例 (陰性 $\rightarrow \pm$ ) & 1 例（3+ $\rightarrow$ 陰性） & 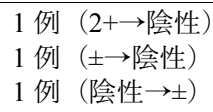 \\
\hline 尿糖 & & 変化なし & 変化なし & 変化なし & 変化なし \\
\hline 尿潜血 & & 変化なし & 1 例（陰性 $\rightarrow \pm ）$ & 1 例（ $\pm \rightarrow$ 陰性） & 変化なし \\
\hline ウロビリノーゲン & & 変化なし & 変化なし & 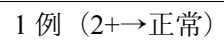 & 変化なし \\
\hline \multirow{2}{*}{$\begin{array}{l}\text { 最高血圧 } \\
\text { (mmHg) }\end{array}$} & 摂取前 & $125 \pm 9$ & $121 \pm 14$ & $116 \pm 19$ & $116 \pm 13$ \\
\hline & 4 週間後 & $120 \pm 8$ & $123 \pm 9$ & $116 \pm 17$ & $116 \pm 12$ \\
\hline \multirow{2}{*}{$\begin{array}{l}\text { 最低血圧 } \\
\text { (mmHg) }\end{array}$} & 摂取前 & $73 \pm 8$ & $76 \pm 8$ & $76 \pm 12$ & $73 \pm 9$ \\
\hline & 4 週間後 & $73 \pm 5$ & $80 \pm 5$ & $74 \pm 11$ & $74 \pm 6$ \\
\hline \multirow{2}{*}{$\begin{array}{l}\text { 心拍数 } \\
(\mathrm{bpm})\end{array}$} & 摂取前 & $78 \pm 11$ & $78 \pm 11$ & $83 \pm 13$ & $64 \pm 3$ \\
\hline & 4 週間後 & $82 \pm 14$ & $82 \pm 15$ & $80 \pm 12$ & $75 \pm 9$ \\
\hline
\end{tabular}

数值は平均值士標準偏差 


\section{4. 血液凝固系検査}

血液凝固系検查の結果を表 6 に示した。飲料 1 の 3 本 摂取群に打いて PT（\%) の有意な増加と PT 比の減少傾 向を，飲料 2 の 3 袋摄取群に扣いて APTT の増加傾向を それぞれ認めたが，基準值範囲内の変動であり安全上問 題となるものではなかった。

\section{QOL 調查}

QOL 調査に用いた SF-32V2 $2^{\mathrm{TM}}$ は健常人や疾病患者の 健康関連の QOL を包括的に評価するために国際的に使 用されている尺度である。表 7 に日本の国民標準值に基 づいたスコアリングによる得点を示した。飲料 1 の 1 本
摂取群に打いて全体的健康感が向上する傾向にあり，ま た，飲料 1 の 3 本摂取群において日常役割機能が低下寸 る傾向にあったが，いずれも有意な変動ではなく，安全 性に影響するものではなかった。

\section{6. 有害事象}

飲料 1 の 1 本摂取群に打いて摂取 3 日目に軽度の軟便 1 例を認めた。 また，飲料 1 の 3 本摂取群において摂取 8 日目に軽度の軟便 1 例，摂取開始から 4 日間軽度の軟 便 1 例，拱取 17 日目と 20 日目に軽度のたちくらみ 1 例 を認めた. 飲料 2 の 3 袋摂取群に扣いて摄取 11 日目に軽 度の気分不快感 1 例を認めた。これらは一過性の軽度の

表 6 血液凝固系検査

\begin{tabular}{|c|c|c|c|c|c|c|}
\hline 評価項目 & 基準値 & & $\begin{array}{c}\text { 飲料 } 1 \\
1 \text { 本摂取群 }\end{array}$ & $\begin{array}{c}\text { 飲料 } 1 \\
3 \text { 本摂取群 }\end{array}$ & $\begin{array}{c}\text { 飲料 } 2 \\
1 \text { 袋掑取群 }\end{array}$ & $\begin{array}{c}\text { 飲料 } 2 \\
3 \text { 袋摂取群 }\end{array}$ \\
\hline \multirow{2}{*}{$\mathrm{PT}$ 秒（秒） } & \multirow{2}{*}{$10.5 \sim 13.5$} & 摂取前 & $11.7 \pm 0.4$ & $12.0 \pm 0.8$ & $11.6 \pm 0.7$ & $11.7 \pm 0.2$ \\
\hline & & 4 週間後 & $12.0 \pm 0.8$ & $11.9 \pm 0.6$ & $11.7 \pm 0.7$ & $11.9 \pm 0.5$ \\
\hline \multirow{2}{*}{ РT\%（\%) } & \multirow{2}{*}{$70 \sim 130$} & 摂取前 & $95 \pm 6$ & $92 \pm 11$ & $97 \pm 9$ & $96 \pm 2$ \\
\hline & & 4 週間後 & $95 \pm 11$ & $95 \pm 9^{*}$ & $98 \pm 11$ & $95 \pm 7$ \\
\hline \multirow{2}{*}{ PT 比 } & \multirow{2}{*}{$0.85 \sim 1.15$} & 摂取前 & $1.03 \pm 0.04$ & $1.05 \pm 0.07$ & $1.02 \pm 0.06$ & $1.03 \pm 0.02$ \\
\hline & & 4 週間後 & $1.04 \pm 0.07$ & $1.03 \pm 0.06^{\dagger}$ & $1.02 \pm 0.06$ & $1.03 \pm 0.04$ \\
\hline \multirow{2}{*}{ PT-INR } & & 摂取前 & $1.03 \pm 0.04$ & $1.05 \pm 0.07$ & $1.02 \pm 0.06$ & $1.02 \pm 0.01$ \\
\hline & & 4 週間後 & $1.04 \pm 0.07$ & $1.04 \pm 0.06$ & $1.02 \pm 0.07$ & $1.04 \pm 0.04$ \\
\hline \multirow{2}{*}{ APTT（秒） } & \multirow{2}{*}{$24.3 \sim 36.0$} & 摂取前 & $28.8 \pm 1.8$ & $29.9 \pm 3.9$ & $29.3 \pm 1.6$ & $27.4 \pm 1.7$ \\
\hline & & 4 週間後 & $29.2 \pm 1.8$ & $28.7 \pm 2.1$ & $29.6 \pm 2.1$ & $28.0 \pm 1.8^{\dagger}$ \\
\hline
\end{tabular}

数值は平均值土標準偏差

摂取前との比較 : ${ }^{\dagger} \mathrm{p}<0.1,{ }^{*} \mathrm{p}<0.05$

表 7 QOL 調查

\begin{tabular}{|c|c|c|c|c|c|}
\hline 評価項目 & & $\begin{array}{c}\text { 飲料 } 1 \\
1 \text { 本摂取群 }\end{array}$ & $\begin{array}{c}\text { 飲料 } 1 \\
3 \text { 本摂取群 }\end{array}$ & $\begin{array}{c}\text { 飲料 } 2 \\
1 \text { 袋摂取群 }\end{array}$ & $\begin{array}{c}\text { 飲料 } 2 \\
3 \text { 袋摂取群 }\end{array}$ \\
\hline \multirow{2}{*}{ 身体活動 } & 摂取前 & $57 \pm 3$ & $57 \pm 4$ & $56 \pm 5$ & $59 \pm 0$ \\
\hline & 4 週間後 & $58 \pm 1$ & $58 \pm 1$ & $55 \pm 7$ & $59 \pm 0$ \\
\hline \multirow{2}{*}{ 日常役割機能 } & 摂取前 & $54 \pm 4$ & $55 \pm 3$ & $55 \pm 2$ & $56 \pm 0$ \\
\hline & 4 週間後 & $56 \pm 1$ & $53 \pm 5$ & $55 \pm 2$ & $51 \pm 10$ \\
\hline \multirow{2}{*}{ 身体痛及 } & 摂取前 & $59 \pm 6$ & $59 \pm 4$ & $55 \pm 8$ & $59 \pm 5$ \\
\hline & 4 週間後 & $59 \pm 4$ & $58 \pm 8$ & $53 \pm 9$ & $56 \pm 7$ \\
\hline \multirow{2}{*}{ 社会生活機能 } & 摂取前 & $49 \pm 9$ & $52 \pm 7$ & $57 \pm 8$ & $57 \pm 3$ \\
\hline & 4 週間後 & $50 \pm 10$ & $52 \pm 7$ & $55 \pm 10$ & $56 \pm 6$ \\
\hline \multirow{2}{*}{ 全体的健康感 } & 摂取前 & $49 \pm 4$ & $50 \pm 6$ & $53 \pm 8$ & $53 \pm 7$ \\
\hline & 4 週間後 & $54 \pm 5^{\dagger}$ & $49 \pm 8$ & $55 \pm 10$ & $51 \pm 7$ \\
\hline \multirow{2}{*}{ 活力 } & 摂取前 & $48 \pm 9$ & $54 \pm 5$ & $57 \pm 0$ & $56 \pm 2$ \\
\hline & 4 週間後 & $53 \pm 5$ & $54 \pm 5$ & $56 \pm 2$ & $53 \pm 9$ \\
\hline \multirow{2}{*}{ 日常役割機能 } & 摂取前 & $52 \pm 9$ & $53 \pm 5$ & $57 \pm 0$ & $55 \pm 5$ \\
\hline & 4 週間後 & $52 \pm 7$ & $45 \pm 11^{\dagger}$ & $57 \pm 0$ & $54 \pm 5$ \\
\hline \multirow{2}{*}{ 心の健康 } & 摂取前 & $49 \pm 7$ & $52 \pm 7$ & $54 \pm 5$ & $56 \pm 5$ \\
\hline & 4 週間後 & $52 \pm 7$ & $50 \pm 7$ & $53 \pm 6$ & $55 \pm 5$ \\
\hline
\end{tabular}

数値は平均值土標準偏差 摂取前との比較 : $\mathrm{p} p<0.1$ 
表 8 免疫機能検査

\begin{tabular}{|c|c|c|c|}
\hline 評価項目 & & $\begin{array}{c}\text { 飲料 } 1 \\
1 \text { 本摂取群 }\end{array}$ & $\begin{array}{c}\text { 飲料 } 2 \\
1 \text { 袋摂取群 }\end{array}$ \\
\hline \multirow{2}{*}{ NK 活性（\%） } & 摂取前 & $39.3 \pm 15.0$ & $43.0 \pm 15.7$ \\
\hline & 4 週間後 & $38.1 \pm 15.7$ & $42.0 \pm 16.5$ \\
\hline \multirow{2}{*}{ Th1: IFN $\gamma^{+} / \mathrm{IL}^{-} \quad(\%)$} & 摂取前 & $20.5 \pm 6.8$ & $17.3 \pm 10.7$ \\
\hline & 4 週間後 & $21.1 \pm 6.3$ & $19.3 \pm 10.1 * *$ \\
\hline \multirow{2}{*}{ Th2: $\mathrm{IFN}^{-} / \mathrm{IL}^{+} \quad(\%)$} & 摂取前 & $2.0 \pm 0.7$ & $1.8 \pm 0.7$ \\
\hline & 4 週間後 & $2.0 \pm 0.5$ & $2.2 \pm 1.2$ \\
\hline \multirow{2}{*}{ Th0: $\mathrm{IFN}^{+} / \mathrm{IL}^{+} \quad(\%)$} & 摂取前 & $0.8 \pm 0.5$ & $0.7 \pm 0.2$ \\
\hline & 4 週間後 & $1.0 \pm 0.4$ & $0.8 \pm 0.4$ \\
\hline \multirow{2}{*}{$\mathrm{IFN}^{-} / \mathrm{IL}^{-} \quad(\%)$} & 摂取前 & $76.7 \pm 7.4$ & $80.3 \pm 11.3$ \\
\hline & 4 週間後 & $75.9 \pm 6.7$ & $77.7 \pm 10.8^{* *}$ \\
\hline \multirow{2}{*}{ Th1/Th2 (CD4) 比 } & 摂取前 & $11.3 \pm 4.8$ & $10.3 \pm 5.9$ \\
\hline & 4 週間後 & $10.8 \pm 3.5$ & $10.4 \pm 6.6$ \\
\hline
\end{tabular}

数值は平均值土標準偏差

摂取前との比較 : **p $<0.01$

症状であり，その後の摂取継続によって自然に消失して 扣り，安全上問題となるものではなかった。

\section{7. 免疫機能検査}

免疫機能検查の結果を表 8 に示した。飲料 2 の 1 袋掑 取群に打いて, Th1 (IFN $\left.\gamma^{+} / \mathrm{IL}^{-}\right)$の有意な増加, IFN $\gamma^{-} / \mathrm{IL} 4^{-}$ の有意な減少を認めた。 Th2 (IFN $\left.\gamma^{-} / \mathrm{IL}^{+}\right), \mathrm{Th} 0\left(\mathrm{IFN} \gamma^{+} /\right.$ $\left.\mathrm{IL}^{+}\right), \mathrm{Th} 1 / \mathrm{Th} 2$ 比, NK 活性には有意な変動は認めなかっ た.

\section{考 察}

フコイダンは昆布やワカメ，モズクなどの褐藻類に含 まれる多糖成分であり，ガゴメ昆布には乾燥重量あたり 数\%のフコイダンが含まれる. フコイダンは, 日本人の 藻類の食経験を考光ても極めて安全性の高い成分と考兄 られる。また，今回研究に用いたフコイダンはヨウ素や 塩分など過㮃摂取が望ましくない低分子成分が除去され ている. しかし，フコイダン自体のヒトに対する安全性 を詳しく評価した報告はこれまでないことから，本試験 では 32 人の健常成人を対象にして，1 食あたり $200 \mathrm{mg}$ あるいは $300 \mathrm{mg}$ のガゴメ昆布フコイダンを含む 2 種類 の飲料の 1 日目安量とその 3 倍量の 4 週間摂取に打ける 安全性評価を実施した。 その結果, 血液生化学的検査, 血液学的検查に扬いて一部の項目に統計学的に有意な変 動が認められたが，いずれも基準值内の変動であり安全 上問題となる変動は見られなかった，尿蛋白検査では， 32 名中 3 名が摂取前に陽性であったが摂取後では全例 が陰性に改善した. Zhang らはへイマン腎炎ラットを用 いて真昆布由来のフコイダンの経口投与が腎炎に伴ら尿
蛋白上昇を抑制することを報告している9 の結果は運動や生活様式によっても影響を受ける場合が あり今回の結果についてはより慎重な検討を加える必要 があるが，フコイダンの腎機能改善機能に関して研究を 進めることが今後の課題と考える。 また, 肝機能状態な ぞを示す尿ウロビリノーゲンに括いては，陽性から陰性 への改善が 1 例認めら机た。 ガゴメ昆布フコイダンは肝 臓の強力な再生力を担ら肝細胞増殖因子 (HGF) の産生 を促進することが知られている ${ }^{10)}$. また，D-ガラクトサ ミン誘発肝障害ラットに打いてヒバマタ由来のフコイダ ンの経口投与が肝臓機能の保護作用を示すことが報告さ れている ${ }^{11)}$ ，今後，フコイダンの肝機能改善作用につい てヒトを対象に研究を進める意義があると考兄られる.

フコイダンは, 硫酸化多糖のへパリンと構造が類似し て和り, 抗血液凝固作用や血栓形成抑制作用について研 究が進められている ${ }^{12}$. 水谷らは, 動脈ならびに静脈血 栓形成モデルに怙いて, $0.05 \sim 0.25 \%$ のガゴメ昆布フコイ ダン水溶液の 30 日間の経口投与が血栓形成を抑制する ことを明らかにしている ${ }^{3)}$. 血栓形成は脳梗塞や心筋梗 塞などの脳血管系疾病の主な発生原因であり, ガゴメ昆 布フコイダンの摂取がそれら疾病の予防に期待できる可 能性がある。しかしながら, 過度に血液凝固反応が抑制 されると正常な止血現象が妨げられる恐れがあり，例え ば術後の回復等に影響がでる可能性もある. 今回の試験 に打いて, 飲料 1 の 3 本摂取群に PT\%の有意な低下が認 められたが基準値範囲内での変動であったことから, 安 全上は特に問題ないと考兄られた. Irhimeh らは, ワカメ 由来のフコイダンを 10 名の健常成人に 12 日間摂取させ た試験に打いて抗血液凝固作用は認められなかったと報 告している ${ }^{13)}$. 従って，フコイダンは血液凝固系に执い 
ても極めて安全性が高いと考兄られた。ささらに, QOL 調 査に扒いて特に安全上問題となる点は認められず, 試験 食品に起因寸る重篤な有害事象も認められなかった。

今回の試験に打いて飲料 2 亿配合された白榆木茸属キ ノコエキスはブナシメジを原料としたエキスであり，成 分としてきのこテルペン $\left(\right.$ Hypsiziprenol $\left.\mathrm{A}_{9}\right)$ を含む. きの こテルペンは担がん動物への投与に氺いて腫瘍の増殖を 強く抑制することが報告されている ${ }^{14)}$ 。また，きのこテ ルペンはヒト前骨髄性白血病細胞の HL-60 と扎いてカ スパーゼ群を活性化しアポトーシスを誘導する ${ }^{15,16)}$ ，今 回の試験食品の飲料 2 には白榆木茸属キノコエキスが 1 食あたり $7500 \mathrm{mg}$ 含まれており，1 日目安量ならびに 3 倍量の摂取いずれにおいても安全上問題となる現象は認 められなかったことから，白榆木茸属キノコエキスの七 トでの安全性も示されたと考兄られる。ただし，本試験 の被験者は平均年齢が 20 歳台の若年健常成人であり, 今 後さらに幅広、年齢層の七トに対するガゴメ昆布フコイ ダンや白榆木茸属キノコエキスの安全性を調べる必要が ある.

ガゴメ昆布フコイダンの抗腫瘍作用には NK 細胞の活 性化などが深く関与している7)。水谷らは，担がん動物 に执いて低下した NK 活性がガゴメ昆布フコイダンの経 口投与に沶いて回復することを報告している。 また，ガ ゴメ昆布フコイダンの抗腫瘍作用は抗 NK 抗体により NK 細胞の働きをブロックした場合には減弱することか ら, NK 細胞の活性化が抗腫瘍作用に重要であると考兄 られる。 ガゴメ昆布フコイダンは，マクロファージや樹 状細胞などに作用し IL-12 の産生を促進することが知ら 孔ている. IL-12 は NK 細胞や T 細胞を活性化する働き を持つサイトカインであり，これにより全身免疫が活性 化されると考光られる.さらに，ガゴメ昆布フコイダン はマウス腸管由来のパイエル板細胞と共に培養すると IFN- $\gamma$ の産生を強く促進することから腸管免疫を活性化 することで全身免疫を高める可能性がある. 今回の免疫 機能検査の結果, 飲料 2 の 1 袋摂取群において Th1 細胞 集団の有意な増加が認められた。 Th1 細胞はへルパー T 細胞のらち細胞性免疫の調整を担う細胞であり, 抗原提 示細胞からの IL-12 や Th1 細胞自体が産生する IFN- $\gamma$ の 刺激により Th0 細胞から分化する. Th1 細胞は癌や感染 症の予防に重要な細胞であることから，健常成人に沶い てガゴメ昆布フコイダンの摂取により Th1 細胞が増加 したことはフコイダンの免疫機能への効果を示している 可能性があり興味深い.今回の試験は比較的免疫機能が 正常に保持されている若年の健常成人を対象としたこと から，NK 活性なぞには大きな変化がなかったと考兄ら れた。 今後はガゴメ昆布フコイダンの免疫機能への有用
性を評価する為に，免疫機能が低下したヒトを対象とし て研究することが重要な課題であると考えられる.

\section{結 論}

健常成人 32 名を対象に, ガゴメ昆布フコイダンを $200 \mathrm{mg}$ あるいは $300 \mathrm{mg}$ 含む飲料の 1 日目安量とその 3 倍量をそれぞれ 4 週間摂取する安全性評価試験を実施し た，その結果，血液検査，尿検查，QOL 調査に安全上問 題となる変動が見られなかった，また，試験食品に起因 乙安全上特に問題となる有害事象は認められなかった. 免疫機能検査では Th1 細胞集団の増加が認められた．以 上より，ガゴメ昆布フコイダンはヒトに対して非常に安 全性が高い食品素材であると考兄られた。

\section{参 考 文 献}

1) Li B, Lu F, Wei X, et al. Fucoidan: structure and bioactivity. Molecules 2008; 13: 1671-1695.

2) 酒井 武，加藤郁之進. 海藻由来フコイダンとそのオリゴ 糖の構造と生物活性. バイオサイエンスとインダストリ一. 2002; 60: 23-26.

3) 水谷滋利, 廣田有花, 出口寿々ら。 ガゴメ昆布フコイダン の機能性. New Food Industry 2008; 50: 22-34.

4) Koyanagi S, Tanigawa N, Nakagawa $H$, et al. Oversulfation of fucoidan enhances its ant-angiogenic and antitumor activities. Biochem Pharmacol 2003; 65: 173-179.

5) 水谷滋利, 酒井 武, 加藤郁之進. ガゴメ昆布 (Kjellmaniella crassifolia) フコイダンの抗がん作用. Food Style 21 2008; 12: 73-75.

6) 速水祥子，中原寛子，大野木宏. ガゴメ昆布海藻エキスの FGF-7 産生促進による育毛効果. FRAGRANCE JOURNAL 2010; 9: 72-75.

7) 水谷滋利. ガゴメ昆布 (Kjellmaniella crassifolia) フコイダン の免疫活性化作用. Food Style 21 2010; 14: 29-31.

8) 大野木宏, 滝本裕子, 鈴木里芳ら. ガゴメ昆布 (Kjellmaniella crassifolia) 由来フコイダンの遺伝毒性試験による安全性の 評価. 日本補完代替医療学会誌. 2011: 8: 61-65.

9) Zhang Q, Li N, Zhao T, et al. Fucoidan inhibits the development of proteinurea in active Heymann nephritis. Phytother Res 2005; 19: $50-53$.

10) 加藤郁之進, 酒井 武, 佐川裕章. フコイダンの機能性と その効果. ジャパンフードサイエンス. 2000; 39: 43-47.

11) Kawano N, Egashira $Y$, Sanada H. Effect of dietary fiber in edible seaweeds on the development of D-galactosamine-induced hepatopathy in rats. J Nutr Sci Vitaminol 2007; 53: 446-450.

12) Mourao PAS. Use of sulfated fucans as anticoagulant and antithrombotic agents: Future perspectives. Curr Pharm Des 2004; 10: 967-981.

13) Irhimeh MR, Fitton JH, Lowenthal RM. Pilot clinical study to 
evaluate the anticoagulant activity of fucoidan. Blood Coagulation and Fibrinolysis 2009; 20: 607-610.

14) 水谷滋利, 河合高志, 榎 竜嗣ら. ブナシメジ (Hypsizigus marmoreus) から分離されたテルペンの腫瘍成長抑制作用. 日食科工会誌. 2006; 53: 55-61.

15) 水本裕子, 大野木宏, 水谷滋利ら. ブナシメジ由来ポリテ
ルペンの HL-60 白血病細胞におけるアポトーシス誘導機

構. 日食科工会誌. 2008; 55: 612-618.

16) 水本裕子, 大野木宏, 水谷滋利ら. ブナシメジ由来 Hypsiziprenol $\mathrm{A}_{9}$ による cAMP 経路の抑制を介した HL-60 白血病細胞のアポトーシス誘導. 日本きのこ学会誌. 2008; 16: $143-148$.

\title{
ABSTRACT \\ Safety of fucoidan from Gagome kombu (Kjellmaniella crassifolia) in healthy adult volunteers
}

\author{
Hiromu OHNOGI ${ }^{1}$, Yusuke NAKADE ${ }^{2}$, Yuko TAKIMOTO ${ }^{3}$, Akiko SEKIYA $^{4}$, Takuya KAWASHIMA ${ }^{3}$, \\ Andrew SCHNEIDER ${ }^{5}$, Takanari ARAI ${ }^{5}$, Kazuo UEBABA ${ }^{6}$, Nobutaka SUZUKI $^{3}$ \\ ${ }^{1}$ TAKARA BIO INC. \\ ${ }^{2}$ Kanazawa University Hospital \\ ${ }^{3}$ Department of Complementary and Alternative Medicine Clinical Research and Development, \\ Kanazawa University Graduate School of Medical Science \\ ${ }^{4}$ Division of Health Sciences, Kanazawa University Graduate School of Medical Science \\ ${ }^{5}$ Endowed Center for the Advancement of Pregnancy, Perinatal and Infant Care, \\ Kanazawa University Graduate School of Medical Science \\ ${ }^{6}$ Institute of Eastern Medicine, Teikyo-Heisei University
}

Object: Fucoidan is a sulfated polysaccharide in brown marine algae. Gagome kombu (Kjellmaniella crassifolia) is a Japanese edible seaweed and contains fucoidan abundantly. Recently, it was reported that fucoidan from Gagome kombu (GKF) had antitumor, immune-enhancing and anti-coagulant activities. In this study, we conducted a safety of GFK on the healthy adult.

Methods: Thirty-two healthy volunteers were randomly divided into 4 groups and administered a standard volume and three times volume of two kinds of test drinks containing GKF for 4 weeks.

Result: No abnormal changes were observed after test drinks ingestion on blood chemistry, urinalysis, hematological data and blood pressure. No severe adverse events related to test drinks were observed. Moreover, increase of Th1 cells was observed in immunological analysis.

Conclusion: This study suggests that GKF is safe in healthy adults.

Key words: fucoidan, Gagome kombu, safety, immune function 